\title{
Poles Apart. Have There Been Any Male and Female Graves?
}

\author{
Tove Hjørungdal
}

\begin{abstract}
This paper discusses archaeological burial analysis, and some ideological problems with the application of sex/gender defined as a dual positions construction, i.e. sex/gender as the male-female metaphor. Through traditional criteria as well as through multidimensional methods of defining male and female graves, we reproduce a binary assymetrical interpretation of gender. Alternatively, the ongoing discussion on ideological and theoretical aspects of gender is regarded as a challenge to archaeological burial analysis. A gender critical point of departure opens up the possibilities of looking away from the old tradition of burial analysis by which gender has been fixed in advance through a given male-female bipolarity.
\end{abstract}

Tove Hjorungdal, Department of Archaeology, University of Umea, S-901 87 Umeå, Sweden.

In this paper I will discuss some of my thoughts on the issue of gendering prehistoric burials. The background to the question posed in the title is found in two very different articles I recently had the pleasure of reading. The most recent of these papers is printed in Current Swedish Archaeology Vol. 1 (Burström \& Carlsson eds. 1993). Bo Petré, the author, discusses male and female finds and symbols in Germanic Iron Age graves in the Mälar area, Sweden (Petré 1993:149 ff). Marie Louise Stig Sørensen is the author of the other article in question, which is found in a voluminous Canadian conference report, "The Archaeology of Gender" (Walde \& Willows eds. 1991). Sørensen explores gender with reference to Bronze Age dress and cloth as we know it from oak coffin burials in Denmark (Sørensen 1991:121 ff).

What, then, is my intention with this slightly ironical question asked? I believe my discussion will draw attention to the fact that traditional archaeological ways of classifying burials into "male and female" are about to be problematized. The reason for this is elucidated as well. This paper is as well a synopsis of a more extensive work on gender and material culture, with special respect to burials. In spite of the fact that I am working on a critical evaluation of traditional ways of gendering burials, I do not see any point in trying to give a definite answer to the question of how to study burials and gender. Anyway, it might not even be possible to give a definite answer. Accordingly, my aim is rather to try to develop my own thoughts by examining the field of gendering burials in general, and by studying at least some aspects of a gender critical perspective on a deeply rooted tradition within this archaeological research area. 


\section{METHODOLOGY VERSUS THEORY AND IDEOLOGY}

Taken together, Petré's and Sørensen's papers respectively, point to the fact that there currently seem to be two different ways of, or opinions on, studying gender and burials as a matter of principle. These two approaches contrast sharply with each other, and not only on the surface. The explanation to these fundamentally different approaches is that these scholars delineate two separate ways of coping with the question of gender and burials, as well as of coping with gender and science in general. At first glance the most obvious difference seems to be that Petré focuses his attention on methodological means while Sørensen focuses on theory, or ideology. Let us take a closer look at the two authors, and try to get a more well-founded understanding of the issues stated. Briefly, Petré's method is to test three independent variables against each other, namely an osteological variable, one variable of find associations, and one variable of symbolic/ religious/social meaning. This approach, despite its refinement, is in agreement with a traditionalist way of grouping burial finds at two different poles, "male burials" at the one pole, and "female burials" at the opposite pole. Petré, through his work, hands down a long tradition which has usually not been leading in any theoretical discussion on the concept of gender, in advance of applying it methodologically to an archaeological source material. As a matter of consequence, the ideological definition of gender seems to be taken for granted. An opinion of gender as a non-problematic matter is as well expressed through the choice of terminology. In this case it is the notion of "sex" which is used, and which also is accepted without any evaluation, neither of its theoretical background nor of its implications on scientific conditions (cf. Petré 1993).

The definitions and interpretations made through the use of the term of "sex" are implicit, however. It makes one think in biologically biassed terms, rather than in terms that include critical aspects on cultural constructs. We are dealing with a scholarly tradition with a commonly held, but not explicitly defined, gender ideology. The classification into "male" versus "female" burials might, however, be the archaeologist's most explicit way of contributing to a traditional dual interpretation of gender. As such, this system of burial classification is inclined to make up a sturdy caryatid in the ancient building called gender biassed or patriarchal science. Sørensen has long since contributed to the critique of a traditional gender ideology in archaeology (e.g. Sørensen 1988).

Sørensen' s point of departure is anchored in an explicit feminist problematizing of established bipolarities, e.g. the "male-female" metaphor. Sørensen is looking for alternative ways of defining gender; and she also tries to interpret burial finds on the basis of definitions which are in accordance with her explicit theoretical and ideological interpretations of gender. A critical opinion of gender constructs is expressed through the terminological praxis as well, namely, through the use of the notion of "gender" as an alternative to "sex." Gender is as such interpreted mainly as socially and culturally defined categories. Gender from this point of view is understood as a very complex and multifaceted matter. The existence of several possible gender categories is suggested as an alternative to the two which are in polar positions to each other. Gender is to be conceptualized as reflexive, local, contextrelated, and even as quite relative (cf. Sørensen 1991).

Theoretical discussions on sex/gender, gender identity, and gender relations are mainly held within such disciplines as e.g. history and sociology (e.g. Braidotti 1992; Rimmen Nielsen 1992; Saarinen 1992; Wetterberg 1992; Widerberg 1992). The theoretical discussion within archaeology is, however, also a very vigorous one (e.g. 
Nordbladh \& Yates 1990; Engelstad 1991a; 1991b; Dommasnes 1992; Wylie 1992). These discussions remind us of the fact that a definition of gender/sex is a difficult matter. It is not as simple as to say that "sex" is biologically related and "gender" culturally related. In fact, the definitions of gender and sex have always been difficult and are by now a more complicated matter than ever (cf. Saarinen 1992; Widerberg 1992; Nordbladh \& Yates 1990). Some scholars might even go so far as to explain their definitions of sex and gender each time they use the terms, even throughout one and the same essay (Widerberg 1992).

Anyway, the use of "gendering" instead of "sexing" in the archaeological classification of prehistoric burials helps to make the point explicit that we should not look upon humankind and its genders as determined by biology (alone).

A theoretical admission of gender as complex and as contextually constituted, as an alternative to a universal dichotomy, might, within the field of gendering burials, inspire archaeologists to seek alternatives to our well-established "male-and-female" graves.

\section{THE MALE AND FEMALE BURIALS OF ARCHAEOLOGY}

In this paper the main issue is the sex/ gender determination of burials through material means. Osteology is not explicitly discussed. The ideological problems of a binary male-female pair is, as Petré's article illustrates, not solved through the addition of osteological variables to material and symbolic ones. There are several recent analyses on burial material within this tradition, and among these, Petré's analysis is one of the most up to date as far as methodology is concerned. The archaeologist's main task has in this respect been to recognize the two given and materially a priori defined "sex" categories, and to do this in a way that looks convincing to the rest of us. The most important aim of this methodological cluster is to get as many burials as possible within the two categories of "male" versus "female." One of the overwhelming practical problems with this way of "sexing" burials is the large amount of "unsexed" graves usually left over. The consequences of this problem are also in accordance with my own personal experience of "sexing" Early Iron Age graves in western Norway (Hjørungdal 1991:70 ff). The problem is well recognized by collegues discussing burials within other geographical areas and other chronological periods (cf. Jennbert 1992:96 with references).

As already stated, the polarization of prehistoric burials into a male-female pair is a theme which is well established as well as generally accepted, as far as the criteria chosen for man and woman can be regarded as sufficient. We have to take a look back at the very distant history of archaeology to find the roots of the matter. "Male-female" as a bipolarity to my knowledge was first defined as an archaeological topic by the association of antiquarians in Schwerin, Mecklenburg in the $1830 \mathrm{~s}$, and published as a scientific theme in their periodical Mecklenburgisches Jahrbuch in 1837 (Bartsch ed. 1837). At this early stage there is also a discussion led by the Norwegian bishop and antiquarian Jacob Neumann in connection with "King Valder's Grave" on the island of Valderøy, western Norway. Neumann seems to have found it difficult to settle on the question of whose grave his working team actually had discovered - was it the grave of King Valder, or was it his housewife's? There were no weapons in the grave, so the latter alternative was preferred (Neumann 1837).

During rather long periods of time the discussion on men's and women's burials was given extensive room in some of the periodicals of the 19th century. This theme was most frequently discussed by a close circle of antiquarians, in contact with each 
other through letters, through visits in each others museums or homes, as well as through conferences. They were the members of a north German/Danish antiquarian-scholarly culture during the second half of the 19th century. I have already mentioned one of the local milieus within this culture, namely the one in Schwerin, and its pioneering role in defining "male-female" as an issue of archaeological burial investigation. The discussion continued for about 50 years. We can follow the discussion led in Mecklenburgisches Jahrbuch until the $1880 \mathrm{~s}$. By this time the matter was also investigated at other museums within the scholarly-cultural context mentioned. When the materials of the new Museum of National Antiquities of Copenhagen were rearranged, one of the themes of discussion, initiated by the antiquarian Worsaae was the Bronze Age costumes found in Danish oak coffins. One central question was that of which costume could be male and which could be female (Worsaae 1872a; 1872b). The questions delineated on male and female finds to a certain extent were further developed by Worsaae's assistants, Engelhardt, Müller and Bahnson (Engelhardt 1876; 1877; Müller 1876; 1884; Bahnson 1886). We can make a tentative conclusion that questions of this kind simply seem to have become almost an integrated part of the research schedule among the GermanDanish scholars discussed.

Johanna Mestorf in Schleswig-Holstein was another of these scholars. Of special interest in this respect is her work on daggers in burials defined as female burials (Mestorf 1889), besides her analyses of women's graves with beads (Mestorf 1900). The phenomenon of daggers in female graves had, in fact, already caused trouble for Müller, and it led to discussions on female temperament as well (cf. Müller 1876; Mestorf 1889).

Throughout the 19 th century several different material criteria of sex (gender), especially female gender, were suggested. The point of departure was above all the question of what could be recognized as "male tools," e.g. weapons, versus "female tools," e.g. sewing needles (Bartsch ed. 1837:157). The lack of weapons could well define a burial as female (cf. Neumann 1837). A burial lacking sewing needles, on the other hand, was never interpreted as a male burial to my knowledge. As time went on, the most frequently used criteria of male identity versus female, were weapons versus jewellery (e.g. Lisch 1840). These particular material things have acquired the status of metaphors par exellence of "malehood" and "womanhood" within archaeology. This is still the situation today (cf. Petré 1993 with references; Hjørungdal 1991 with references).

In my current research I am trying to make a general overview as well as a more detailed discussion of 19th-century archaeological gender determinations of burials. The present paper is based on issues chosen from the more extensive works. So far, I have been occupied almost exclusively with the 19th century, and to some extent also with the period from the 1970 s on. The long period in between is not analysed at all concerning gender and burials. It seems already quite clear, however, that this issue has not been among the most important ones in Scandinavian archaeology during the period in question. One of the important exceptions in this respect is Berta Stjernquist's dissertation published in the middle of the present century (Stjernquist 1955). The question of gender identity in burials was once again brought into the archaeological focus about 1970 . This time archaeologists were defining several new and even alternative criteria of gender/sex in burial customs. New methods have been tried out, methods recognized through their multidimensional orientation. One of the aims has been to find safer criteria through which we can recognize two sexes through 


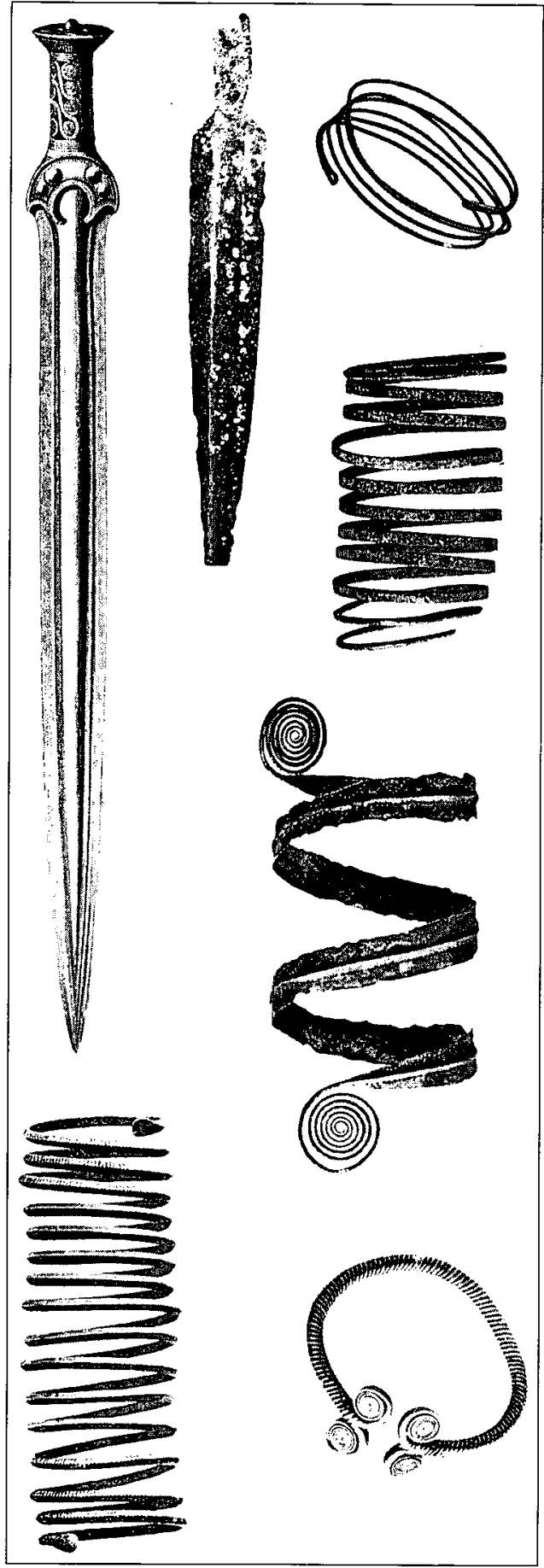

Fig. 1. Early Bronze Age weapons and jewellery from Mecklenburg. From Beltz 1910.

Sword: plate 23 dagger: plate 25; jewellery: plate 32. a priori given bipolar gender definitions. With this statement I am back to where I started, and the discussion will to a certain extent be further developed below. First, however, I will present a preliminary version of some thoughts on the historical, cultural and scholarly context, seen in relation to ways of angling the discussion on gender and burial in this essay.

\section{SOME THOUGHTS ON HISTORICAL CONTEXT}

In my view, we are dealing with questions which are intimately tied to cultural and temporal conditions when discussing the issue of gendering burials. The notion of gender as male opposing female is a structuring principle of 19 th century science as well as of 19th century culture and politics in general. A gender ideology which explained the male-female bipolarity as a natural one, was transformed into social practice through the bourgeois ideal of public opposing private. We are now at the core of the matter. To be able to understand the problematics of archaeological gender determinations, it is necessary to see this in the light of how neighbouring disciplines have delineated the 19th and 20th centuries, i.a. history, the history of ideas and of culture and mentalities (cf. e.g. Ambjörnsson 1974; Habermas 1988; Aamodt 1990; Frykman \& Löfgren 1990). During the 19 th century we meet the ideal of the needle-working woman in the doll's house, in contemporary 19 th-century ideology and society, as well as through interpretations of prehistoric material remains. Through recent and current analyses of prehistoric material culture, we meet the woman transcending the limits created i.a. through 19th-century archaeology. The woman moving from the domestic sphere into the public one is constituted through focusing on alternative items in graves, as well as through alternative interpretations of burials. Since the $1970 \mathrm{~s}$ we have focused our attention on such matt- 
ers as work tools, task specialization, and areas of responsibility on the basis of gender (e.g. Dommasnes 1982; Gustafson 1981; Lillehammer 1985; Hjørungdal 1991). The female characters created by us are in many respects similar to women of our own generations. We have, for example, the Viking tradeswoman (Stalsberg 1987), the housewife in charge of a farm as well as of aspects of social life and procreation (e.g. Dommasnes 1982; Lillehammer 1985; Hjørungdal 1991). It is not surprising to find that we, like 19th-century antiquarians, interpret as well as create gender in prehistory depending on how gender is known to ourselves. As a matter of fact, archaeologists have always been inclined to problematize old criteria in order to look for new, relevant criteria of sexing/gendering graves. Another aspect of the question of finding new criteria is that it is female criteria which are most frequently focused on, and which also most frequently change. This point in itself illustrates opinions on maleness and femaleness, and might be evaluated in future discussions.

Today it seems important to change again regarding the theme of gender and burials - and this time in more radical ways than ever, if we are willing to accept the implications of Sørensen's way of approaching this area of research. It is a fact that an androcentric dual oppositions construction already has been problematized within archaeology, and within different fields of the subject (e.g. Conkey \& Spector 1984; Nordbladh \& Yates 1990; Dommasnes 1987; Engelstad 1986; 1991a; $199 \mathrm{lb}$, and references in these works). It is also a fact that there is an admission of the consequences which feminist critisism has had on archaeological interpretations (cf. Dommasnes 1992 with references).

To focus on Sørensen again, it seems no longer sufficient to define safe criteria of "male" versus "female" when we are trying to find out who is buried in the graves we are investigating, and which gender these persons might belong to. This way of seeing is irrelevant to a gender critical research, and it is instead the basic construction of gender understood as the bipolar metaphor of "male-female" that is problematized (cf. Sørensen 1991). It might, in fact, be possible to think in other terms than those of a dichotomized world made up of complementary and exclusive malefemale spheres, where the "male-female burials" model constitutes a miniature of this universe.

\section{DISCUSSION}

The enterprise of trying to think in terms of complexity instead of in terms of bipolarity, sounds like a way of forcing - or I would prefer to say inviting - our brains to systematize the world through quite different principles than those internalized through the process of socialization most of us have been through. Probably it is not just my own brain which needs to adjust. Further, what in fact is the dual positions definition of gender? Is it just a bipolar fiction, included in the strategies of ruling? Issues like this have been raised by poststructuralist critics and are i.a. discussed by the Finnish sociologist Aino Saarinen (Saarinen 1992). In archaeological terms we might transform this question by asking, what is the dual positions definition of gender, of male-female? Is it, when graves are concerned, just a way of classifying burials, which will probably soon be outdated? In this classificatory respect, as well as in the everyday life of academia, a masculine-feminine schism is more than mere fiction and it is not enough to try to think it away.

However, let us continue with the field of burial analysis. Sørensen's way of approaching burials and gender opens up new paths. Examples of similar theoretical approaches to material culture are already given, also in Scandinavian archaeology 
(e.g. Engelstad 1991c).

But gender critical approaches to different genders in burials have never been exemplified as clearly as they have been in Sørensen's studies. She uses the concept of "gender differentiation" and discusses interpretation and construction of gender through different costumes known from Bronze Age oak coffins. A person's appearance is the heart of the matter, and on the basis of this she was able to define three different gender categories which she names as one male one and two female ones; i.e. gender identity is interpreted as being expressed through appearance. In spite of the fact that Sørensen uses terms like male and female (do we have any alternatives?), the gender categories are not grouped complementary or bipolar to each other; and female is not evaluated against the background of what is expected to constitute some kind of normal appearance (cf. Sørensen 1991:127). Sørensen's interpretative groups can accordingly not be compared with Worsaae's classical categories of male and female dress. Their ideological backgrounds are too distant from each other for that.

In view of what has been stated so far, I am inclined to conclude that primary questions in the future will not be how to find more cautious, secure, and up-to-date a priori material/osteological criteria of defining male versus female burials. Instead, within the field of burial studies there seems to be a strong need to define what gender/sex is supposed to mean on an ideological level, in advance of trying to say something about which genders we are dealing with in grave contexts. Multifaceted and contextual interpretations of gender might also open up possibilities in other respects. Through the traditonal application of methods of gender polarity, several prehistoric people were deprived of a sexual identity/gender identity. They did not conform to our dualistic interpretation of the world. Through gender critical definitions, there are possibilities of throwing new light on burials put aside because they were neither "male" nor "female." This kind of problem concerns not least my own previously mentioned work. Iron Age people buried only with pottery or a simple tool, remained without a gender identity because of the lack of weapons or jewellery (Hjørungdal 1991:70 ff). Only people given an elaborate burial were given a gender identity through traditional methods of sexing burials. As such, the problem is not only one of discrimination against gender, but also a problem of discrimination against social group, e.g. class. I am not going to develop this issue further in this essay, but I might be able to delineate the question later on. From a gender critical approach, it might as well be important to have the opportunity of revising interpretations of elaborate burials, burials with which there seemed to be no problems of recognizing gender. One of the points of departure of this paper, Sørensen's essay on Danish oak coffins, is in itself an elucidating example of re-gendering elaborate burials from a theoretical and gender critical perspective.

Some ideological problems of gendering prehistoric burials have been discussed. The background to this discussion was found in two current archaeological essays, as well as in aspects of my own project on gender and material culture. As a point of departure for further discussion on the topic we can make the conclusion that there seems to have been three general approaches when the engendering of burials is concerned. First, there is the traditional opinion of gender, related to a 19th century world view of a man's world versus a woman's world through the use of various traditional material objects. Second, there is the transcendental view, which includes the development of multivariable methods. Through this approach, espescially since the 1970 s, one tried to define new and untraditional roles for men and women respectively. Both of 
these directions of gendering burials do, however, structure the world through dichotomies. Third, there is the gender deconstructive view which want us to leave binary gender definitions. My main point has been that it seems urgent to make clear how one defines gender from an ideological and theoretical point of view before deducing gender identities from burials. The question is, to put it rough, whether one

\section{REFERENCES}

Ambjörnsson, R. 1974. Kvinnofrågan i Sverige. Uppkomst och utveckling under 1800-talet. Häften för Kritiska Studier 7-8, 1974.

Bahnson, B. Kr. 1886. Broncealderens Mandsog Kvindegrave. Museets Forøgelse 186885. Aarbøger.

Bartsch, A. (ed) 1837. Fragen, deren Beantwortung bei Aufgrabung vorchristlicher Grabdenkmäler vom Verein für meklenburgische Geschichte und Alterthumskunde gewünscht wird. Mecklenburgisches Jahrbuch.

Beltz, R. 1910. Die vorgeschichtlichen Altertümer des Grossherzogtumes MecklenburgSchwerin. Vollständiges Verzeichnis der im Gross-herzoglichen Museum zu Schwerin bewahrten Funde. Bearbeitet von Robert Beltz. Textband. Tafelband.

Braidotti, R 1992. Køn og post-køn: En illusions fremtid? Kvinder, køn og forskning 3/1992. København.

Burström, M. \& Carlsson, A. (eds) 1993. Current Swedish Archaeology. Vol. 1.

Conkey, M. \& Spector, J. 1984: Archaeology and the Study of Gender. In: Schiffer (ed): Advances in Archaeological Method and Theory. Vol. 7.

Dommasnes, L.H. 1982. Late Iron Age in Western Norway. Female Roles and Ranks as Deduced from an Analysis of Burial Customs. Norwegian Archaeological Review Vol. 15/ 1-2.

- 1987. Tanker rundt et program for arkeologisk kvinneforskning. K.A.N. Kvinner i Arkeologi i Norge 5 . wants to reproduce asymmetrical power relations in science or not. As a contrast to the 160 year old tradition of a binary positions classification of graves, archaeologists have already created possibilities which do not necessarily fix gender or gendered burials in rigid binary positions poles apart.

English revised by Laura Wrang.

- 1992. Two Decades of Women in Prehistory and in Archaeology in Norway. A Review. Norwegian Archaeological Review Vol. 25/1.

Engelhardt, C 1876. Egekister fra Borum Æshøi. Illustreret Tidende. Nr. 890, 15de Oct. 1876.

- 1877. Skeletgrave paa Sjæland og i det østlige Danmark, en skitse fra ældre jernalder. Aarbøger.

Engelstad, E. 1986. Stone Age Studies - A Gender Perspective. Kontaktstencil 28-29. Århus.

- 1991a. Feminist Theory and Post-Processual Archaeology. In: Walde \& Willows (eds) 1991: The Archaeology of Gender. Proceedings of the 22nd Chacmool Conference. Calgary.

- 1991b. Images of Power and Contradiction: Feminist Theory and Postprocessual Archaeology. Antiquity. Vol. 65 No. 248. Sept. 1991.

- $1991 \mathrm{c}$. The symbolism of everyday life in prehistory. Archaeology and Environment 11. Umeă.

Frykman, J. \& Löfgren, O. (1979)1990. Den kultiverade människan. Liber. Malmö.

Gustafson, L. 1981. Krumkniver og kvinnearbeid. Nicolay.

Habermas, J. (1962)1988. Borgerlig offentlighet. Kategorierna "privat" och "offentligt" $i$ det moderna samhället. Övers av J. Retzlaff. Arkiv Moderna Klassiker. Lund.

Hjørungdal, T. 1991. Det skjulte kjønn. Patriarkal tradisjon og feministisk visjon i arkeologien belyst med fokus pà en jernalderkontekst. Acta Archaeologica Lundensia. Series in $8^{\circ}$ Nr. 19. Lund (With English summary by Alan Crozier). 
- n.d. 1): Den arkeologiska könsbedömningens kulturhistoria. Report. Unpublished manuscript. Institute of Archaeology. Umeå.

- n.d .2): En gammal historia. Arkeologins mansoch kvinnogravar. To be published in Arkeologi i Norr. Umeå.

Jennbert, K. 1992. Changing Customs . Reflections on Grave Gifts, Burial Practices and Burial Rituals during Period III of the Bronze Age in Southeast Scania. In: Papers of the Archaeological Institute, University of Lund 1991-1992. New Series Vol. 9. Lund.

Lillehammer, G. 1985. Forhistoriens kvinner fram fra skjulestedet. Nytt om Kvinneforskning 1985/2.

Lisch, Fr. 1840. Aus der Zeit der Kegelgräber. Gesammelter Inhalt ganzer Gräber. Kegelgrab zu Ruchow. Mecklenburgisches Jahrbuch.

Mestorf, J. 1889. Dolche in Frauengräbern der Bronzezeit. Correspondenz-Blatt der Deutschen Gesellschaft für Anthropologie, Ethnologie und Urgeschichte. XX Jahrgang, Nr. 10, Okt. 1889.

- 1900. Glasperlen aus Frauengräbern der Bronzezeit. Mittheilungen des Anthropologischen Vereins in Schleswig-Holstein. Dreizehnten Heft: 1.

Müller, S. 1876. Bronzealderens Perioder. En undersøgelse i forhistorisk archæologi. Aarbøger.

- 1884. Mindre Bidrag til den forhistoriske Archæologis Methode. Aarbøger.

Neumann, J. 1837. Kong Valders Grav. Urda I. Nordbladh, J. \& Yates, T. 1990. This Perfect Body, This Virgin Text: Between Sex and Gender in Archaeology. In: Bapty, I \& Yates, T (eds): Archaeology after Structuralism. Routledge. London.

Petré, B. 1993. Male and Female Finds and Symbols in Germanic Iron Age Graves. Current Swedish Archaeology Vol. 1.

Rimmen Nielsen, H. 1992. Køn, kultur, ræpresentation. Nyere tendenser i international kvindehistorisk forskning. Den jyske historiker. Nr.
58-59. Temanr. Kønnet i historien. Århus. Saarinen, A 1992: Feminist research - an Intellectual Adventure? A research autobiography and reflections on the development, state and strategies of change of feminist research. Centre for Women's Studies and Gender Relations. Publications 4/1992. Tampere.

Stalsberg, A. 1987. Tradeswomen during the viking age. Archaeology and Environment 11. Umeå.

Stjernquist, B. 1955. Simris. On Cultural Connections of Scania in the Roman Iron Age. Acta Archaeologica Lundensia. Series in 4:2. Lund.

Sørensen, M. L. S. 1988. Is There a Feminist Contribution to Archaeology? In: $A R C$. Archaeological Review from Cambridge Vol. 7:1, Spring 1988.

-1991. The Construction of Gender Through Appearance. In: Walde \& Willows (eds): The Archaeology of Gender. Proceedings of the 22nd Chacmool Conference. Calgary.

Walde, D. \& Willows, N. D. (eds) 1991: The Archaeology of Gender. Proceedings of the 22nd Chacmool Conference. Calgary.

Wetterberg, C. 1992. Från patriarkat till genussystem - och vad kommer sedan? Kvinnovetenskaplig Tidskrift 3/1992.

Widerberg, K. 1992.Vi behöver en diskussion om könsbegreppet. Kvinnovetenskaplig Tidskrift 4/1992.

Worsaae, J. J. 1872a. Dragter fra den xldre Bronzealder i Danmark I. Illustreret Tidende Nr. 643, 21 .jan. 1872.

- 1872b. Dragter fra den xldre Bronzealder i Danmark II. Illustreret Tidende Nr. 643, 21. jan. 1872.

Wylie, A. 1992. Feminist Theories of Social Power: Some Implications for a Processual Archaeology. N.A.R. Norwegian Archaeological Review. Vol. 25 No. 11992.

Aamodt, S. 1990. Kjærlighet og kvinnefrigjøring ved overgangen til det 19. århundre. Nytt om Kvinneforskning 3/1990. 
